\title{
Investigating the Writing Difficulties on Indonesian Second Language Students in Learning English
}

\author{
Dhevi Arifanita ${ }^{1}$, Joko Nurkamto ${ }^{2}$, Suparno $^{3}$ \\ 1,2,3 Universitas Sebelas Maret Surakarta \\ $\{1$ dheviarifanita@gmail.com\}
}

\begin{abstract}
This study aimed at investigating writing difficulties in the English language faced by second language students. A survey was conducted for this purpose. The data were collected from 30 ESL students consisting of boys and girls as the student participants in some senior high schools in Indonesia. Ten teachers participate in teaching English language for upper and lower levels with different teaching experiences. An essay examination and questionnaire were used as the instruments of this study. The results of the study revealed that Indonesian ESL students have problems in writing tasks, especially in mastering vocabulary, language use (grammar), spelling and punctuation. The practical method including identification, investigation, and solutions should be used for teaching English language in order to cope with writing difficulties.
\end{abstract}

Keywords: English language, Writing difficulties, ESL students, Vocabulary, Language use.

\section{INTRODUCTION}

\section{a. Background of the Study}

Writing may have difficulties in some aspects of writing skill such as proper use of grammar, conventions, punctuation, capitalization, spelling, and some of the basic and initiating aspects of writing. It is also an unpleasant piece of work for both teachers and learners in ESL classes. Leki (1992) declared that ESL students complain about learning and focusing on the English word order or word forms. According to Adams and Keene (2000), cited in Al-Khasawneh (2010), English can make a strong contribution to education and students' efficiencies in communication. Learners are expected to master content areas which are all taught in English, such as "mathematics, social studies, science, and business". Therefore, in order to handle academic tasks, ESL students need to do their best to write proficiently. Pak-TaoNg (2003) said that the first idea which comes to mind is that when you think about writing, it is a part of obligatory course work. The thought seems to be true for students who should write long or short assignments. If writing is just an anxiety for students, it means they should do nothing except a chore. They are not likely to go beyond learning. Moreover, Pak-TaoNg (2003) suggested that writing consists of a lot of activities which result in understanding. Such an understanding includes a process of thinking about the topic, notes gathering, data collection, etc. which makes a reflective thought for you at the end. 


\section{b. Objective of the Study}

The study consists of three objectives. First, it has purpose to explore the difficulties in writing essay writing faced by ESL students. It specifically aimed to know difficulties in writing English language related to conventions, punctuations and language use (grammar) for students with English as a second language. Second, it intended to get information about ESL teachers' feedbacks on students' writing problems and third, to suggest some possible ways to overcome the writing problems faced by Indonesian ESL students.

\section{c. Research Questions}

Based on the objectives of the study, the following questions are raised.

1. How frequent do Indonesian ESL students make mistakes in writing?

2. What are the Indonesian ESL teachers' feedbacks on students' writing skills?

\section{d. Literature Review}

\section{The Importance of Writing}

Al-Khasawneh (2010) argued that huge number of international contacts, regarding nonnative to non-native communication and deals are carried out through English in a massive number of settings, including trade, diplomacy, tourism, journalism, science and technology, politics, etc. Therefore, the existence of competent writers and speakers of English is of a great importance for today's world. According to Tan and Miller (2008), writing is an intentional, social communication that involves literacy as well. Furthermore, it is taken as a means of social practices, through which patterns of participation, gender preferences, networks of support and collaboration, patterns of time use, space, tools, technology and resources are applied. In addition, through the interaction of writing with reading and written language with other semiotic modes, the symbolic meanings of literacy, and the broader social goals take place. This is exactly what literacy serves in the lives of people and institutions. Zamel (1983), a pioneer in ESL writing research, considered writing process as a "non-linear, exploratory, and generative process whereby writers discover and reformulate their ideas as they attempt to approximate meaning" (p.165).

\section{Writing Problems and Difficulties}

ELT practitioners always found many difficulties in writing task. ESL teachers in Indonesia confirm the problems in writing development, especially in conventions, and punctuation. "Writing is such an important learning tool because it helps students to understand ideas and concepts better" (Voon Foo, 2007, p. 4). Lack of English language proficiency is the main cause of lots of difficulties that ESL learners have in their writing tasks. The writing task is challenging because many ESL students face more complicated problems, which may be either cultural or linguistic ones (Musa, Lie, \& Azman, 2012). These problems may create difficulty for both teachers and ESL writers, so giving attention to different aspects of variation can help ESL students adapt themselves to the writing standards. Researchers recommend that students should be supported by teachers to take control of their own writing. As a result, a responsible teacher would be a reactive reader, a person who helps students recognize and resolve writing problems. 
$\mathrm{Yu}$ (2008), contended that there are different aspects of writing, such as controlled composition model, built-in three- or five-paragraph model, basic organizational and informative assumptions, the simplified writing assignment, the assumption that supposes working without the help of each student or only with the instructor for comprehensive feedback, usage of grammar and handbooks or even lectures, and the linear composition model based on "outlining, writing, and editing". All these aspects of the writing process have made a remarkable success in ESL classrooms.

According to Leki (1992), ESL students are also disappointed with difficulties in understanding word implication and meaning. It is obvious that there is a disparity between writing in the first and the second language. They are also tackling with difficulties in writing assignments, meeting deadlines as well as getting the best quality of their final writing. As a result, the current study not only concerns about some of the common writing problems among ESL students, but also suggests some solutions based on teachers and the researchers' experiences which can be helpful and supportive in developing writing skills.

\section{METHODOLOGY}

\section{a. Design}

This study used a survey research design to examine the common writing problems among ESL students in some senior high schools in Indonesia and teachers' experienced feedback towards students' writing problems. Such a design was applied to collect data randomly from 30 ESL students and 10 teachers through a questionnaire and a sample essay writing by students.

\section{b. Instruments}

The instruments used in this study were a questionnaire and an essay examination. The questionnaire was developed from Mohammad Nazim and Jalal Ahmad (2012). The questionnaire consisted of items on the types of errors that commonly occur in essay writing including conventions, punctuations, and language use. The purpose of the questionnaire was to collect data on teachers' perceptions about students' common writing errors based on their experience to investigate whether their perceptions match with students' writing errors based on a sample essay writing test. The essay examination sheet was developed to check students' probable writing errors and also to compare these committed errors with teachers' experienced feedback on students' writing problems. The topic given to the students to write their essays was, "The effect of plastic bag in our environment".

\section{c. Procedure}

The participants of this study consist of students and teachers that were selected from some senior high schools in Surakarta, Indonesia. First, the questionnaires were distributed to the teachers. The teachers were given 30 minutes to fill out them. The questionnaire consisted of 3 parts, namely conventions, and punctuation, and language use. Each of these parts contained 9 Likert-scale items $(1=$ Always. $2=$ Sometimes and $3=$ Never $)$ and the teachers were supposed to circle the suitable answers. The student participants were selected randomly from some available classes. One day after the meeting for filling out the questionnaire, the ten teachers distributed the essay examination papers among the students. Examination sheets were given to the students in classrooms to write the essays immediately. They were given 45 minutes to write the essay. Their essays were immediately collected. Then, the essays were examined by the 
researchers to check for possible intended errors and also to see whether these errors can match with teachers' perceived feedbacks on students' writing errors. The researchers assessed students' essays for any writing errors in conventions, punctuation, and language use. The 10 questionnaires were also analyzed to compare the students' errors in the essays with teachers' feedbacks on students' writing errors.

\section{FINDINGS AND DISCUSSION}

\section{a) Analysis of Research Questionnaire}

The following tables and figures have been analyzed carefully to present the teachers' opinion on every single writing problem which conveys, according to this study, nine subcategories in every single area of writing (i.e. conventions, punctuation, and the language use) that were stated in the questionnaire. Charts and tables in the following represent the results of the analysis.

\section{b) Conventions}

Table 1 represents the complete list of items for conventions and all 10 teachers' scores on the related items. It can be seen that all teachers believed that their students' writing are only sometimes clear. In other words, students' writings are not always clear. In addition, the majority of participated teachers believed that students have problems in proper use of lines in the paper, beginning of the sentences, writing complete sentences, and their writing length.

Table 1. Teachers Feedback on Students' Convention items

\begin{tabular}{|c|c|c|c|}
\hline ITEMS & ALWAYS & SOMETIMES & NEVER \\
\hline Your students' handwritings are clear & 0 & 10 & 0 \\
\hline Your students make proper use of lines in the paper & 3 & 7 & 0 \\
\hline Your students make proper use of lines in the paper & 6 & 3 & 1 \\
\hline Your students' sentences go from left to right & 6 & 4 & 0 \\
\hline Your students' sentences begin in easy & 1 & 6 & 3 \\
\hline Your students write complete sentences & 2 & 7 & 1 \\
\hline Your students' words/sentences go from right to left & 1 & 3 & 6 \\
\hline Your students write to small or too large & 3 & 7 & 0 \\
\hline Your students use cursive writing & 1 & 5 & 4 \\
\hline
\end{tabular}

Figure 1 shows teachers' feedbacks on conventions errors of students in their writing using a bar chart to make it easy to compare the occurrence of errors. 


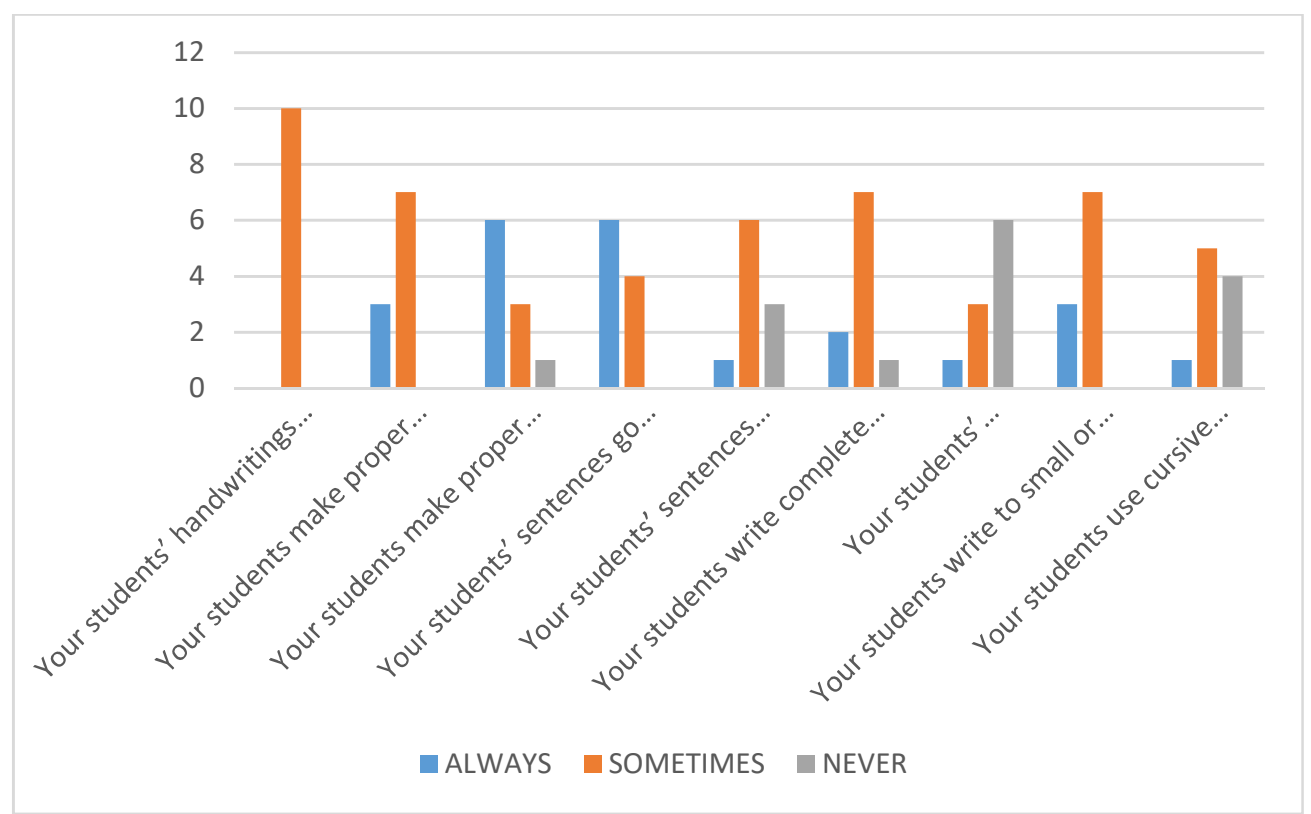

Figure 1. Teachers Feedback on Students' Occurrence of Convention Errors

\section{c) Punctuation}

Table 2 depicts the complete list of items for punctuation and teachers' scores on them. Students also face punctuation problems in essay writing. According to the teachers' responses, students usually have problems or confusion in using question mark, colon or semicolon, apostrophes, and commas while writing essays. It is necessary for teachers to take punctuation problems of students into account, especially when they are correcting students' essays.

Table 2. Teachers Feedback on Students' Punctuation Items

\begin{tabular}{|c|c|c|c|}
\hline ITEMS & ALWAYS & SOMETIMES & NEVER \\
\hline Your students use a full stop at the end of each sentence & 8 & 1 & 1 \\
\hline Your students use a question mark at the end of each question & 2 & 8 & 0 \\
\hline Your students use an exclamation & 1 & 6 & 3 \\
\hline Your students know the proper use of commas & 1 & 9 & 0 \\
\hline Your students always confuse between the full stop \\
and comma & 0 & 8 & 2 \\
\hline Your students confuse with colon and semicolon & 6 & 3 & 1 \\
\hline Your students use question marks in dialogues & 3 & 7 & 0 \\
\hline Your students use commas between words in a list & 3 & 7 & 0 \\
\hline Your students use apostrophes in contractions and possessives & 1 & 8 & 1 \\
\hline
\end{tabular}

Figure 2 shows teachers' feedbacks on punctuation problems of their students' writing in a bar chart according to the occurrence of errors from always to never scale. 


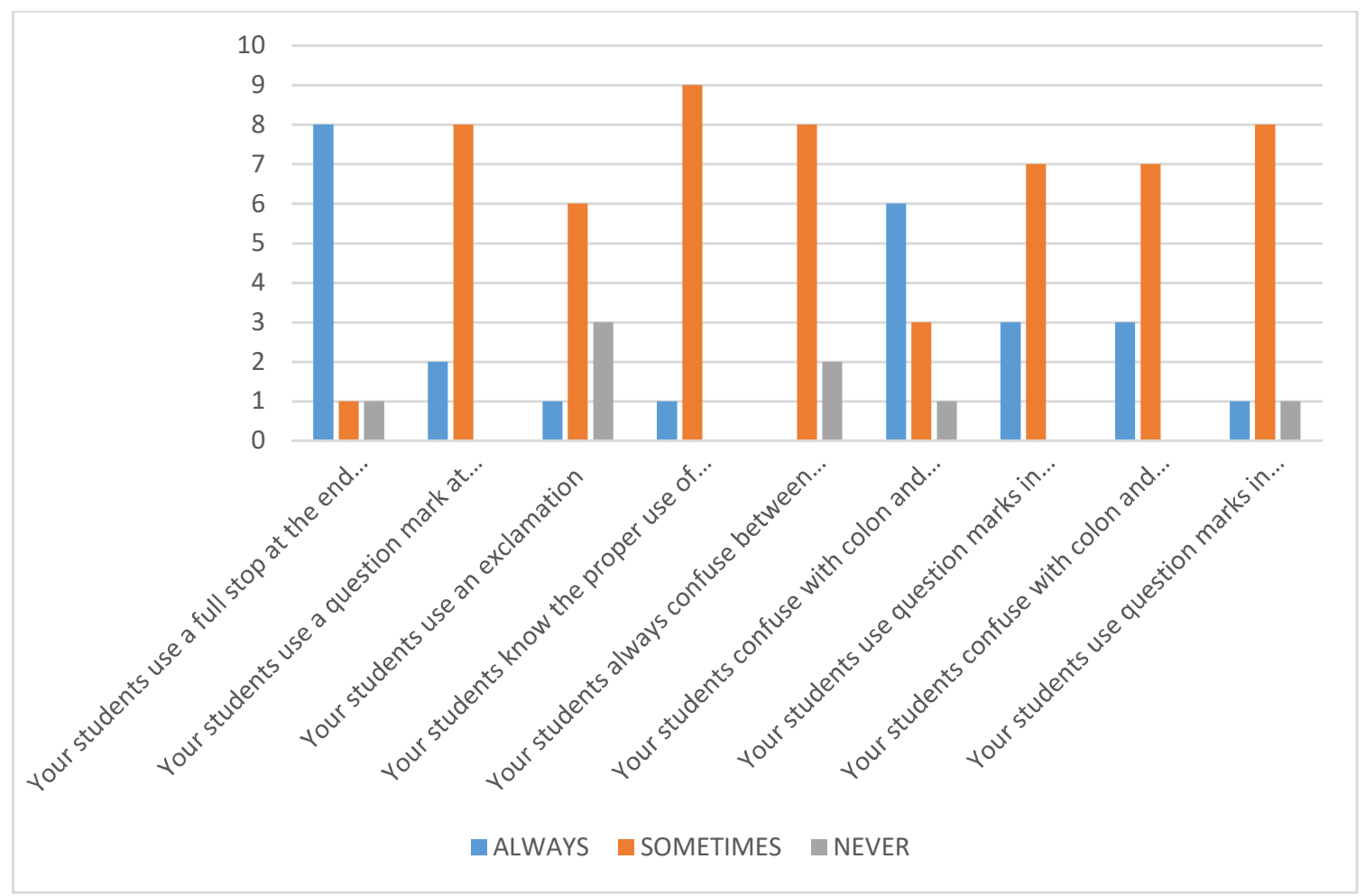

Figure 2. Teachers' feedback on Students' Occurrence of Punctuation Errors

\section{d) Language Use}

Table 3 represents the complete list of items for language use and its score on teachers' feedbacks. They agree that although their students are able to use synonyms/antonym and accurate grammatical structures in their essays, they sometimes struggle using appropriate language. The students also often use L1 words and Bahasa Indonesia sentence patterns in their sentences and writings. Students are also able to use SVO (Subject + Verb + Object), SP (Subject + Predicate) and SVA (Subject + Verb + Adverbial) patterns with minimal errors. Compared with the two previous aspects of writing, it is seen that teachers report more error occurrence in language use. To sum up, students need language support with basic vocabulary items and grammatical structures.

Table 3. Teachers Feedback on Students' Language Use Items

\begin{tabular}{|c|c|c|c|}
\hline ITEMS & ALWAYS & SOMETIMES & NEVER \\
\hline Your students use appropriate language & 0 & 8 & 2 \\
\hline $\begin{array}{c}\text { Your students use synonyms/antonym of words they write a } \\
\text { lot }\end{array}$ & 0 & 9 & 1 \\
\hline $\begin{array}{c}\text { Your student use L1 words in their sentences/writings. } \\
\text { Your students use SVO/SP/SVA patterns correctly }\end{array}$ & 1 & 8 & 1 \\
\hline $\begin{array}{c}\text { Your students use the correct form(s) of the } \\
\text { verb/words. }\end{array}$ & 1 & 8 & 0 \\
\hline
\end{tabular}




\begin{tabular}{|c|c|c|c|}
\hline $\begin{array}{c}\text { Your students use Bahasa Indonesia sentence } \\
\text { patterns. }\end{array}$ & 2 & 5 & 3 \\
\hline $\begin{array}{c}\text { Your students need language support/struggle with the basic } \\
\text { vocabulary. }\end{array}$ & 3 & 6 & 1 \\
\hline Your students use accurate grammatical structures. & 0 & 9 & 1 \\
\hline Your students use awkward phrasing. & 3 & 6 & 1 \\
\hline
\end{tabular}

Figure 3 demonstrates teachers' feedbacks on Language use aspect in their students' writing.

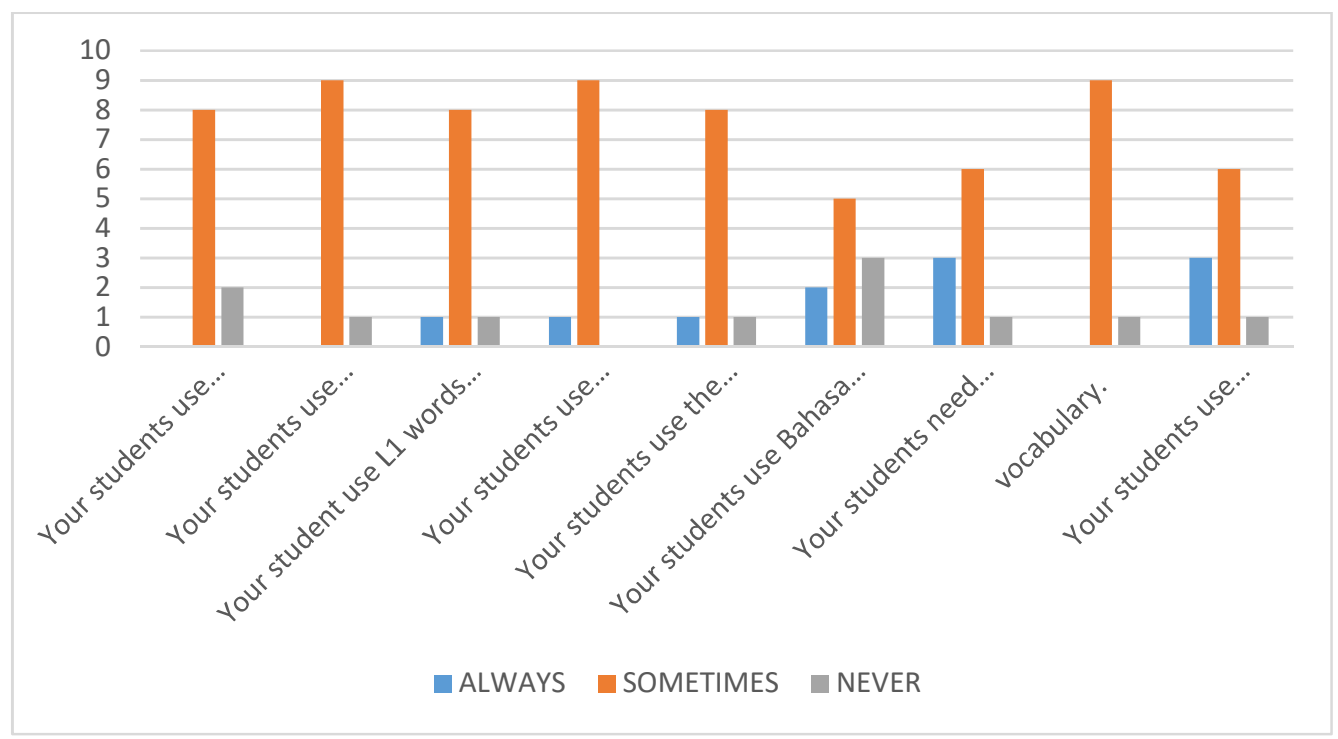

Figure 3. Teachers' feedback on Students' Occurrence of Language Use Errors

\section{e) Analysis of Students' Writing Samples}

Students' essays were analyzed and marked by the researchers to see how many errors they have made based on the three related aspects (i.e. conventions, punctuation, and language use). Table 4 depicts the total number of students' errors on conventions, punctuation, and language use in their essay examinations.

Table 4. Total Writing Errors of Students on Conventions, Punctuation, and Language Use

\begin{tabular}{|c|c|}
\hline Items & Total error of all 30 students \\
\hline Conventions & 52 \\
\hline Punctuations & 65 \\
\hline Language Use & 123 \\
\hline
\end{tabular}

According to table 4 and the 3 intended aspects that were considered to analyze students' essays, it is represented that the students have problems in conventions, punctuation, and more specifically in language use. As it can be observed, with an approximate calculation, the highest error which is done by students in essay writing is language use, whereas the lowest is conventions. Punctuation holds the second position in writing errors among the 3 intended errors. This is also in line with the teachers' experienced feedback on the frequency of students' 
writing errors in the intended aspects. Figure 4 displays all three types of errors in students' writing samples.

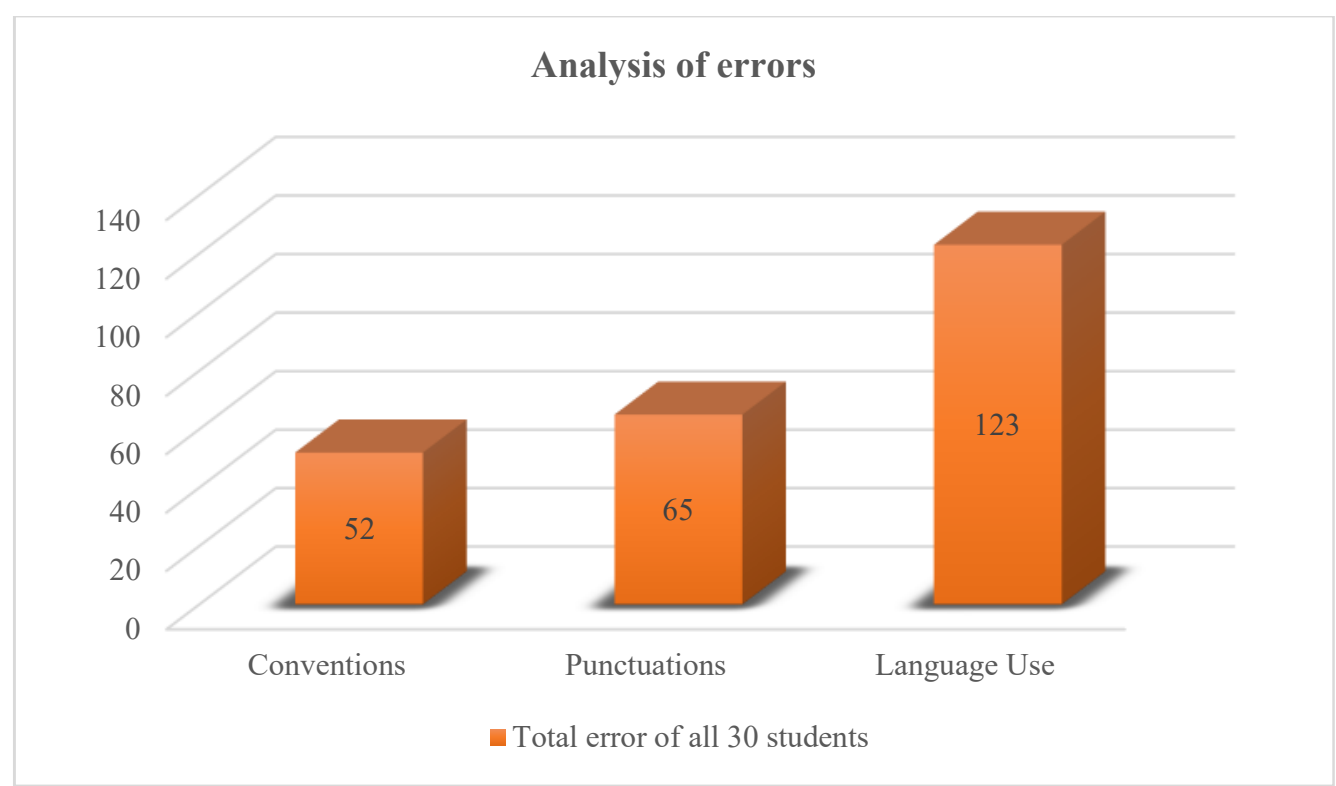

Figure 4. Students Writing Problems on Conventions, Punctuation, and Language Use

\section{CONCLUSION}

This study is conducted based on several researches carried out regarding students' writing skill and writing problems in ESL context. The focus of this study has been Indonesian ESL senior high school students' writing errors and teachers' feedbacks on such errors. The writing error items studied in this research were Language use, conventions, and punctuation. The findings of this study confirmed the previous research (Maros, Hua, and Khazriyati, 2007; Musa, Lie, \& Azman, 2012) reporting ESL students 'writing problems in different areas, particularly in language use. It can be concluded from the findings that ESL students need more improvement on English language proficiency and language use. Then, they require training on punctuation and writing conventions respectively. Additionally, teacher training should also be taken seriously into account in order to improve and develop ESL students' language proficiency in general and writing skill in particular.

There are some suggestions that have been proposed by some experienced teachers and the researchers based on their experience to reduce the problems in conventions, punctuation, and language use:
a) Writing classes must witness more practice than delivering lectures
b) The teacher must explain the use of all the punctuation marks
c) The teacher must explain the rules of capitalization
d) The teacher must engage the learners in memory/vocabulary games
e) The teacher must motivate and encourage the learners before the actual writing
f) The teacher must provide the language support on every single topic
g) The teacher must act as a prompter to assist the student at times
h) Students should be encouraged to do home assignment as much as possible 


\section{References}

[1] Al-Khasawneh, S.M.F. (2010). Writing for Academic Purposes: Problems Faced by Arab Postgraduate Students of the College of Business. ESP World, 9(2), 28. retrieved from http://www.esp-world.info

[2] Gue'nette, D. (2007). Is feedback pedagogically correct? Research design issues in studies of feedback on writing. Journal of Second Language Writing, 16, 40-53.

[3] Hedgcock, J., \& Lefkowitz, N. (1996). Some input on input: Two analyses of student response to expert feedback in L1 writing. Modern Language Journal, 80(3), 287-308. http://dx.doi.org/10.1111/j.1540-4781.1996.tb01612.x

[4] Hyland, K. (2003). Second Language Writing. Cambridge: Cambridge University Press.http://dx.doi.org/10.1017/CBO9780511667251

[5] Leki, I. (1992). ESL composing: Strategies and perceptions. In B. Leeds (Eds.), Writing in a Second Language: Insights from First and Second Language Teaching and Research. Longman: Addison-Wesley.

[6] Mourtaga, K. (2004). Investigating Writing Problems among Palestinian Students: Studying English as a Foreign Language, Bloomington, Indiana: AuthorHouse.

[7] Musa, C.N., Lie, Y.K., \& Azman, H. (2012). Exploring English Language Learning and Teaching in Malaysia, Journal of Language Studies. 12(1), 35-51.

[8] Nazim, M., \& Ahmad, J. (2012). Developing Writing Skills: A Practical Remedy of Common Writing Problems among Students of Writing Skills Courses at Preparatory Year. Journal of Language in Indi, 12(3), 348-360.

[9] Pak-TaoNg. P. (2003). Effective Writing: A Guide for Social Science Students, the Chinese University of Hong Kong.

[10] Ramaprasad, A. (1983). On the definition of feedback. Behavioral Science Journal, 28(1), 4-13.

[11] Tan, E.K., \& Miller, J. (2008). Writing in English in Malaysian High Schools: The Discourse of Examinations, England: Routledge.

[12] Tony, S., \& Matsuda, K. P. (2001). Land Mark Essays: On EL Writing, New Jersey, Lawrence Erlbaum Associates, Inc.

[13] Voon Foo, C. T. (2007). The Effects of the Process-Genre Approach to Writing Instruction on the Expository Essays of ESL Students in a Malaysian Secondary School. Unpublished $\mathrm{PhD}$ thesis, Universiti Sains Malaysia. Penang, Malaysia.

[14] Yu, H.J. (2008). Interactional Structure in the Writing Process: A Comparison of Three ESL Writing Classes, Unpublished $\mathrm{PhD}$ thesis, Arizona State University, U.S.A.

[15] Zamel, V. (1983). The composing process of advanced ESL students: Six case studies.TESOL Quarterly, 17(2), 165-187. http://dx.doi.org/10.2307/3586647 